\title{
An Update of Bone Morphogenetic Proteins as Biomarker and Therapy for Cancer
}

\author{
Chandi C Mandal ${ }^{1 *}$ and Md Mizanur Rahman 2
}

${ }^{1}$ Department of Biochemistry, School of Life Sciences, Central University of Rajasthan, Rajasthan, India

${ }^{2}$ Department of Medicine, University of Texas Health Science Center at San Antonio, San Antonio, Texas, USA

${ }^{*}$ Corresponding author: Dr. Chandi C Mandal, Department of Biochemistry, School of Life Sciences, Central University of Rajasthan, NH-8, Bandarsindri, Kishangarh-305817, Ajmer, Rajasthan, India, Tel:+919650569396; Fax : +911463238772; E-mail ID: chandicmandal@gmail.com

Rec date: Jan 27, 2015, Acc date: Jan 30, 2015, Pub date: Feb 03, 2015

Copyright: ( 2015 Mandal C, et al. This is an open-access article distributed under the terms of the Creative Commons Attribution License, which permits unrestricted use, distribution, and reproduction in any medium, provided the original author and source are credited.

\section{Introduction}

Inspite of doing extensive research work, cancer is still the leading cause of deaths. Its associated cost accounts a largest economic burden worldwide. Cancers are perhaps the most complicated diseases, since each tumor and/or a subpopulation of tumor cells may have a distinct type of genetic alteration, gene mutation, oncogenic signaling, metabolic features, epigenetic changes and also receive different multiple signals from local environment [1-7]. Cancer forming cells acquire many characteristics resembling to embryonic stem cells. For example, cancer initiating cells (cancer stem cells) and embryonic stem cells, both prefer glycolytic mechanism indicating a similar type of metabolic reprogramming [7,8]. Certain genetic alteration and the signals of tumor microenvironment may promote epigenetic switching which may be responsible for aggressiveness of cancers. Most poorly differentiated cancer cells express many embryonic transcription factors such as Snail, Twist, Zeb1, Sox2 and also modulate expressions of many microRNAs (such as miR-200c, miR-34a, miR-302-367, let-7a) which play crucial role in embryogenesis, and they undergo epithelial to mesenchymal transition (EMT) and regain at least in part their embryonic features $[6,9,10]$. Increased mesenchymal features in epithelial cancer cells make them more invasive, survival during transportation through blood circulation, extravasation from blood vessels, and survival at premalignant sites [6]. However, this increased mesenchymal characteristic does not support their growth at pre malignant sites, until they again undergo mesenchymal to epithelial transition (MET). In fact, disseminated cancer cells at premalignant site need to adjust with the new environment by accepting circumstantial signaling which may lead to develop a distinct type of epigenetic switching, resulting in conversion of EMT to MET, and eventually develop macro-metastasis [6]. Thus, dysregulation of such protein, which regulates embryogenesis or organogenesis may cause tumorigenesis and metastasis. Abnormal expressions of bone morphogenetic proteins (BMPs) which play critical role in embryogenesis, cartilage, and bone formation have been found in various types of cancers, which have been linked with tumorigenesis and metastasis of many cancer types [11-15]. However, the role of BMPs in tumorigenesis still remains a debate [16].

BMPs are a group of proteins which are known to be potent growth factors and morphogens of the TGF $\beta$ superfamily. BMPs transduce intracellular signaling cascades by both canonical and non-canonical pathways [12,17]. In canonical pathway, BMPs transduce their signals by binding with serine/threonine protein kinase receptors, followed by forming heterotetrameric complex of receptor type 1 and 2. This heterotetrameric complex when activated upon phosphorylation, phosphorylates regulatory receptor substrates R-Smads (Smad1,
Smad5 and Smad8), which binds to co-Smad, Smad4 which also transduces TGF $\beta$ signaling, and subsequently undergoes nuclear translocation and regulate gene transcription with aid of other coactivator/co-repressor [12,17]. All BMPs usually mediate their signaling cascade following this basic mechanism. However, BMP-2 and BMP-4 first bind to receptor type I to make complex with receptor type II, whereas BMP-6 and BMP-7 first interact with type II to form complex by recruiting type I $[12,18]$. Therefore, these differences may generate distinct types of intracellular signaling. In non-canonical pathways, BMPs may activate various types of signaling such as PI3K/ AKT, MAPKinase, p38 etc. [13,19-25]. Moreover, several signaling (e.g., Wnt signaling) cross talk to BMP pathway to modulate its functional activity [26]. Our earlier studies have established that BMP-2 activates PI3K/AKT signaling via ROS generation [20]. Moreover, shutting down of PI3K/AKT activity prevents BMP-2 driven Smad binding activity to the promoters of osterix and colony stimulating factor 1 (CSF1) to inhibit osteoblast and osteoclast activity respectively $[21,22]$. Thus, non-canonical signaling pathways work independently and also modulate the canonical pathway. Therefore, detail molecular understanding of BMP signaling is required to explain the functional activity of BMPs in various cell types including cancer cells.

\section{Bone Morphogenetic Proteins and Cancer}

Dysregulation of several types of BMPs (e.g., BMP-2, BMP-4, BMP-6 and BMP-7) have been reported in various cancer tissues [11,13,27-32]. Many research studies through cell culture, animal and human studies have done to investigate the link between BMPs and cancer. The results obtained from different independent research groups are very complex, largely varied in cancer types and very fluctuating from one BMP type to other. Although findings are contradictory, researchers still believe that it might have a dual role in tumorigenesis, similar to TGF $\beta$ [16]. For example, BMP-2 decreases cell proliferation of most cancer types such as colorectal, hepatocellular and osteosarcoma [33-36]. Although, inhibitory effect of BMP-2 on breast cancer growth and proliferation is not much convincing [37, 38], similarly it also has no effect on prostate cancer growth [39]. However, studies support a tumorigenic role of BMP-2 in lung cancer $[28,40]$. Recent evidences also strongly indicate the positive role of BMP-2 on invasiveness of many cancers, such as gastric, bladder, pancreatic, oral, prostate and breast cancer [13,14,23,41-46]. Expression of BMP-2 in cancer tissues often correlates with lymph node metastasis and bone metastasis $[11,13,28]$. Similarly, expression of BMP-2 in ovarian cancer tissues positively correlates with poor survival of ovarian cancer patients [11]. BMP-2, and BMP-6 increase 
the growth of renal cell carcinoma and castration resistant prostate cancer [49,50]. In contrast, they inhibit cell proliferation of some cancers such as breast and myeloma [38,47,48]. BMP-6 also inhibits breast cancer cell migration and invasion [51,52]. In contrast, it increases migration and invasion of prostate cancers [53]. Prostate cancer tissues contain high levels of BMP-6 whereas its expression was found to be low in breast cancer tissues [27,47]. However, BMP-7 often inhibits proliferation and invasion of cells of many cancer types such as breast, prostate, kidney and lung cancers [54-56]. Moreover, xenograft study reveals the inhibition of osteolytic metastasis of breast cancer MDA-MB-231 cells in response to BMP-7 treatment [31]. BMP-7 may also increase tumor dormancy at the metastatic site by increasing senescence of prostate cancer stem cells [57]. In addition, decreased BMP-7 expression in breast cancer tissues is associated with bone metastasis [31] but, BMP-7 positive tumors correlate with bone metastasis [30]. Similarly metastatic prostate cancer cells contain increased level of BMP-7 and it is further increased in case of castration resistant prostate cancers [55]. These raise a question for use of BMP-7 as anticancer therapy.

\section{Molecular mechanism of BMPs in regulation of EMT/MET and metastasis}

Canonical BMP-Smad signaling is often found to be active in many cancers. In addition, BMP-2 signaling may also activate non-canonical PI3K/AKT, MAPKinase, NFKB $[13,23,24,58]$ and also increases matrix mettaloproteinases (MMP-2 and MMP-9) activity which could be responsible for the invasion of cancer cells $[13,23]$. Recent literature evidences that BMP-2 treatment inhibits epithelial marker E-cadherin and promotes mesenchymal protein vimentin resulting in EMT of several cancer types such as gastric cancer, pancreatic cancer and lung cancer $[23,24,41]$. However, BMP-6 and BMP-7 may inhibit EMT of cancer cells such as breast, cholangio carcinoma, and melanoma cancer $[52,59,60]$. Most studies reported that BMP-7 inhibits TGF $\beta$-induced EMT of cancer cells. In this note, we have discussed earlier that TGF $\beta$ and BMPs both use Smad4 to transduce Smad signaling. Thus, it could be the case that the addition of BMPs may use some Smad4 which was used by TGF $\beta$ signaling to inhibit TGF $\beta$-driven EMT. BMPs work through both autocrine and paracrine fashion. Thus, the aberrant amount of BMPs present in the microenvironment of primary tumor site may promote EMT, a crucial feature of cancer invasiveness. Further research study is needed to know the role of BMPs in MET at the metastatic site, since MET is also crucial for the outgrowth of metastases. Thus, the contextual signals originating in the microenvironment near to metastases are very important in the conversion of EMT to MET [6]. This idea indicates that local signals might have a distinct impact at the metastatic site from its primary site. These signals might modulate different types of intracellular signaling cascades of cancer cells by discrete types of epigenetic changes.

\section{BMPs as potential biomarkers}

Abnormal expression of an embryonic gene or factor could lead to develop tumorigenesis and metastasis. Similarly, abnormal expression patterns of BMPs have been found in many cancer tissues as compared to control tissues. Recent studies document an elevated level of serum BMP-2 in advanced gastric cancer patients when compared to control or early stage of cancer patients $[61,62]$. It was found that level of BMP-2 is positively correlated with lymph node metastasis, depth of cancer invasion and grade of tumor histology [62]. Similarly, the serum BMP-2 level is positively associated with stage of lung cancers and metastasis of lung cancer patients [63,64]. Moreover, decreased level of BMP-2 correlates with increased overall survival of lung cancer patients [63]. The serum BMP-2 level was found to be higher in multiple myeloma patients than that of healthy control [65]. Likewise, high expression of BMP-2 in ovarian cancer tissues predicts the shorter survival of cancer patients [11]. Moreover, therapy responding patients show a decreased level of serum BMP-2 as compared to therapy nonresponders, suggesting levels of BMP-2 as a therapy efficacy marker [64]. Thus, the serum BMP-2 could be a diagnostic and prognostic marker for cancer patients. Many extensive researches are needed to determine whether serum BMP-2 can be used for all cancer types or cancer specific. Thus, the levels of other BMPs such as BMP-6, BMP-7, and BMP-4 along with BMP-2 could predict cancer progression and metastasis more efficiently. In future, molecular characterization of BMP signaling networks present in cancers and determining the serum BMPs profile could be a powerful tool to achieve better diagnosis and prognosis of cancer patients.

In summary, BMPs especially BMP-2 may prevent cell proliferation and induce apoptosis of cancers at early stage of cancers, but it might induce metastasis by promoting EMT of epithelial cancers at a later stage of cancers. Recent literature suggests a positive link of microcalcification (seen in breast and other cancers) and invasiveness of cancers [66,67]. Therefore, BMPs might promote physiologic microcalcification in cancer tissues when epithelial cancer cells acquire both osteoblastic property and EMT characteristics [68,69]. Thus, disruption of BMP-2 signaling might be a novel therapeutic strategy for cancer treatment. Therefore on the basis of the above discussion, we propose that the combination of BMP-2 inhibitor with an antiproliferating agent might be a better option to prevent cancer growth and metastasis.

This note just insights an idea, but future study will confirm this concept.

\section{Acknowledgments}

CCM is supported by UGC Start-UP-Grant [30-49/2014 (BSR)] and Central University of Rajasthan, MMR is supported by NIH, NIA K01 (KAG034233A), USA.

\section{References:}

1. Bedi U, Mishra VK, Wasilewski D, Scheel C, Johnsen SA (2014) Epigenetic plasticity: a central regulator of epithelial-to-mesenchymal transition in cancer. Oncotarget 5: 2016-2029.

2. Hanahan D, Weinberg RA (2011) Hallmarks of cancer: the next generation. Cell 144: 646-674.

3. Jones PA, Baylin SB (2007) The epigenomics of cancer. Cell 128: 683-692.

4. Lengauer C, Kinzler KW, Vogelstein B (1998) Genetic instabilities in human cancers. Nature 396: 643-649.

5. Rikova K, Guo A, Zeng Q, Possemato A, Yu J, et al. (2007) Global survey of phosphotyrosine signaling identifies oncogenic kinases in lung cancer. Cell 131: 1190-1203.

6. Tam WL, Weinberg RA (2013) The epigenetics of epithelial-mesenchymal plasticity in cancer. Nat Med 19: 1438-1449.

7. DeBerardinis RJ, Lum JJ, Hatzivassiliou G, Thompson CB (2008) The biology of cancer: metabolic reprogramming fuels cell growth and proliferation. Cell Metab 7: 11-20.

8. Kondoh H, Lleonart ME, Nakashima Y, Yokode M, Tanaka M, et al. (2007) A high glycolytic flux supports the proliferative potential of murine embryonic stem cells. Antioxid Redox Signal 9: 293-299. 
9. Ben-Porath I, Thomson MW, Carey VJ, Ge R, Bell GW, et al. (2008) An embryonic stem cell-like gene expression signature in poorly differentiated aggressive human tumors. Nat Genet 40: 499-507.

10. Navarro A, Monzo M (2010) MicroRNAs in human embryonic and cancer stem cells. Yonsei Med J 51: 622-632.

11. Le Page C, Puiffe ML, Meunier L, Zietarska M, de Ladurantaye M, et al. (2009) BMP-2 signaling in ovarian cancer and its association with poor prognosis. J Ovarian Res 2: 4.

12. Wang RN, Green J, Wang Z, Deng Y, Qiao M, et al. (2014) Bone Morphogenetic Protein (BMP) signaling in development and human diseases. Genes Dis 1: 87-105.

13. Kang MH, Oh SC, Lee HJ, Kang HN, Kim JL, et al. (2011) Metastatic function of BMP-2 in gastric cancer cells: the role of PI3K/AKT, MAPK, the NF-Î०B pathway, and MMP-9 expression. Exp Cell Res 317: 1746-1762.

14. Wen H, Feng CC, Ding GX, Meng DL, Ding Q, et al. (2013) Med19 promotes bone metastasis and invasiveness of bladder urothelial carcinoma via bone morphogenetic protein 2. Ann Diagn Pathol 17: 259-264.

15. Xu G, Tang S, Yang J, Chen K, Kang J, et al. (2013) BMP7 expression in esophageal squamous cell carcinoma and its potential role in modulating metastasis. Dig Dis Sci 58: 1871-1879.

16. Singh A, Morris RJ (2010) The Yin and Yang of bone morphogenetic proteins in cancer. Cytokine Growth Factor Rev 21: 299-313.

17. Chen D, Zhao M, Mundy GR (2004) Bone morphogenetic proteins. Growth Factors 22: 233-241

18. de Caestecker M (2004) The transforming growth factor-beta superfamily of receptors. Cytokine Growth Factor Rev 15: 1-11.

19. Ghosh-Choudhury N, Mandal CC, Das F, Ganapathy S, Ahuja S, et al. (2013) c-Abl-dependent molecular circuitry involving Smad5 and phosphatidylinositol 3-kinase regulates bone morphogenetic protein-2induced osteogenesis. J Biol Chem 288: 24503-24517.

20. Mandal CC, Ganapathy S, Gorin Y, Mahadev K, Block K, et al. (2011) Reactive oxygen species derived from Nox4 mediate BMP2 gene transcription and osteoblast differentiation. Biochem J 433: 393-402.

21. Mandal CC, Drissi H, Choudhury GG, Ghosh-Choudhury N (2010) Integration of phosphatidylinositol 3-kinase, Akt kinase, and Smad signaling pathway in BMP-2-induced osterix expression. Calcif Tissue Int 87: 533-540.

22. Mandal CC, Ghosh Choudhury G, Ghosh-Choudhury N (2009) Phosphatidylinositol 3 kinase/Akt signal relay cooperates with smad in bone morphogenetic protein-2-induced colony stimulating factor-1 (CSF-1) expression and osteoclast differentiation. Endocrinology 150: 4989-4998.

23. Liu J, Ben QW, Yao WY, Zhang JJ, Chen DF, et al. (2012) BMP2 induces PANC-1 cell invasion by MMP-2 overexpression through ROS and ERK. Front Biosci (Landmark Ed) 17: 2541-2549.

24. Hsu YL, Huang MS, Yang CJ, Hung JY, Wu LY, et al. (2011) Lung tumorassociated osteoblast-derived bone morphogenetic protein-2 increased epithelial-to-mesenchymal transition of cancer by Runx2/Snail signaling pathway. J Biol Chem 286: 37335-37346.

25. Fong YC, Li TM, Wu CM, Hsu SF, Kao ST, et al. (2008) BMP-2 increases migration of human chondrosarcoma cells via PI3K/Akt pathway. J Cell Physiol 217: 846-855.

26. Nakashima A, Katagiri T, Tamura M (2005) Cross-talk between Wnt and bone morphogenetic protein 2 (BMP-2) signaling in differentiation pathway of C2C12 myoblasts. J Biol Chem 280: 37660-37668.

27. Thomas BG, Hamdy FC (2000) Bone morphogenetic protein-6: potential mediator of osteoblastic metastases in prostate cancer. Prostate Cancer Prostatic Dis 3: 283-285.

28. Chu H, Luo H, Wang H, Chen X, Li P, et al. (2014) Silencing BMP-2 expression inhibits A549 and H460 cell proliferation and migration. Diagn Pathol 9: 123

29. Liu Y, Chen J, Yang Y, Zhang L, Jiang WG (2012) Îøolecular impact of bone morphogenetic protein 7 , on lung cancer cells and its clinical significance. Int J Mol Med 29: 1016-1024.
30. Alarmo EL, Korhonen T, Kuukasjärvi T, Huhtala H, Holli K, et al. (2008) Bone morphogenetic protein 7 expression associates with bone metastasis in breast carcinomas. Ann Oncol 19: 308-314.

31. Buijs JT, Henriquez NV, van Overveld PG, van der Horst G, Que I, et al. (2007) Bone morphogenetic protein 7 in the development and treatment of bone metastases from breast cancer. Cancer Res 67: 8742-8751.

32. Arnold SF, Tims E, Mcgrath BE (1999) Identification of bone morphogenetic proteins and their receptors in human breast cancer cell lines: importance of BMP2. Cytokine 11: 1031-1037.

33. Zhang Y, Chen X, Qiao M, Zhang BQ, Wang N, et al. (2014) Bone morphogenetic protein 2 inhibits the proliferation and growth of human colorectal cancer cells. Oncol Rep 32: 1013-1020.

34. Zheng Y, Wang X, Wang H, Yan W, Zhang Q, et al. (2014) Bone morphogenetic protein 2 inhibits hepatocellular carcinoma growth and migration through downregulation of the PI3K/AKT pathway. Tumor biology 35: 5189-5198.

35. Rici RE, Alcântara D, Fratini P, Wenceslau CV, Ambrósio CE, et al. (2012) Mesenchymal stem cells with rhBMP-2 inhibits the growth of canine osteosarcoma cells. BMC Vet Res 8: 17.

36. Wang L, Park P, Zhang H, La Marca F, Claeson A, et al. (2012) BMP-2 inhibits tumor growth of human renal cell carcinoma and induces bone formation. Int J Cancer 131: 1941-1950.

37. Chen A, Wang D, Liu X, He S, Yu Z, et al. (2012) Inhibitory effect of BMP-2 on the proliferation of breast cancer cells. Mol Med Rep 6: 615-620.

38. Takahashi M, Otsuka F, Miyoshi T, Otani H, Goto J, et al. (2008) Bone morphogenetic protein 6 (BMP6) and BMP7 inhibit estrogen-induced proliferation of breast cancer cells by suppressing p38 mitogen-activated protein kinase activation. Journal of Endocrinology 199: 445-455.

39. Dai J, Keller J, Zhang J, Lu Y, Yao Z, et al. (2005) Bone morphogenetic protein-6 promotes osteoblastic prostate cancer bone metastases through a dual mechanism. Cancer Res 65: 8274-8285.

40. Ye XY, Niu XM, Tang NW, Xu YH, Li ZM, et al. (2012) Adenovirus mediated knockdown of bone morphogenetic protein 2 inhibits human lung cancer growth and invasion in vitro and in vivo. Int J Immunopathol Pharmacol 25: 967-976.

41. Liao A, Wang W, Sun D, Jiang Y, Tian S, et al. (2014) Bone morphogenetic protein 2 mediates epithelial-mesenchymal transition via AKT and ERK signaling pathways in gastric cancer. Tumour Biol .

42. Kokorina NA, Zakharkin SO, Krebsbach PH, Nussenbaum B (2011) Treatment effects of rhBMP-2 on invasiveness of oral carcinoma cell lines. Laryngoscope 121: 1876-1880.

43. de Carvalho CH, Nonaka CF, de Araújo CR, de Souza LB, Pinto LP (2011) Immunoexpression of bone morphogenetic protein-2 (BMP-2), BMP receptor type IA, and BMP receptor type II in metastatic and nonmetastatic lower lip squamous cell carcinoma. J Oral Pathol Med 40: 181-186.

44. Lai TH, Fong YC, Fu WM, Yang RS, Tang CH (2008) Osteoblasts-derived BMP-2 enhances the motility of prostate cancer cells via activation of integrins. Prostate 68: 1341-1353.

45. Clement JH, Raida M, Sänger J, Bicknell R, Liu J, et al. (2005) Bone morphogenetic protein 2 (BMP-2) induces in vitro invasion and in vivo hormone independent growth of breast carcinoma cells. Int J Oncol 27: 401-407.

46. Katsuno Y, Hanyu A, Kanda H, Ishikawa Y, Akiyama F, et al. (2008) Bone morphogenetic protein signaling enhances invasion and bone metastasis of breast cancer cells through Smad pathway. Oncogene 27: 6322-6333.

47. Hu F, Meng X, Tong Q, Liang L, Xiang R, et al. (2013) BMP-6 inhibits cell proliferation by targeting microRNA-192 in breast cancer. Biochim Biophys Acta 1832: 2379-2390.

48. Ro TB, Holt RU, Brenne AT, Hjorth-Hansen H, Waage A, et al. (2004) Bone morphogenetic protein $-5,-6$ and -7 inhibit growth and induce apoptosis in human myeloma cells. Oncogene 23: 3024-3032.

49. Lee JH, Lee GT, Woo SH, Ha YS, Kwon SJ, et al. (2013) BMP-6 in renal cell carcinoma promotes tumor proliferation through IL-10-dependent M2 polarization of tumor-associated macrophages. Cancer Res 73: 3604-3614. 
50. Lee GT, Jung YS, Ha YS, Kim JH, Kim WJ, et al. (2013) Bone morphogenetic proteinâ€6 induces castration resistance in prostate cancer cells through tumor infiltrating macrophages. Cancer science 104: 1027-1032.

51. Wang C, Hu F, Guo S, Mi D, Shen W, et al. (2011) BMP-6 inhibits MMP-9 expression by regulating heme oxygenase- 1 in MCF-7 breast cancer cells. J Cancer Res Clin Oncol 137: 985-995.

52. Du J, Yang S, An D, Hu F, Yuan W, et al. (2009) BMP-6 inhibits microRNA-21 expression in breast cancer through repressing deltaEF1 and AP-1. Cell Res 19: 487-496.

53. Darby S, Cross SS, Brown NJ, Hamdy FC, Robson CN (2008) BMP-6 overexpression in prostate cancer is associated with increased Id-1 protein and a more invasive phenotype. J Pathol 214: 394-404.

54. Alarmo EL, Pärssinen J, Ketolainen JM, Savinainen K, Karhu R, et al. (2009) BMP7 influences proliferation, migration, and invasion of breast cancer cells. Cancer Lett 275: 35-43.

55. Morrissey C, Brown LG, Pitts TE, Vessella RL, Corey E (2010) Bone morphogenetic protein 7 is expressed in prostate cancer metastases and its effects on prostate tumor cells depend on cell phenotype and the tumor microenvironment. Neoplasia 12: 192-205.

56. Yeh LC1 (2010) In vitro and in vivo studies on the effects of bone morphogenetic protein-7 on human kidney and lung tumor cells. Int J Biomed Sci 6: 176-181.

57. Kobayashi A, Okuda H, Xing F, Pandey PR, Watabe M, et al. (2011) Bone morphogenetic protein 7 in dormancy and metastasis of prostate cancer stem-like cells in bone. J Exp Med 208: 2641-2655.

58. Kang MH, Kim JS, Seo JE, Oh SC, Yoo YA (2010) BMP2 accelerates the motility and invasiveness of gastric cancer cells via activation of the phosphatidylinositol 3-kinase (PI3K)/Akt pathway. Exp Cell Res 316: 24-37.

59. Naber HP, Wiercinska E, Pardali E, van Laar T, Nirmala E, et al. (2012) BMP-7 inhibits TGF- ${ }^{2}$-induced invasion of breast cancer cells through inhibition of integrin $\hat{\mathrm{I}}^{2}$ (3) expression. Cell Oncol (Dordr) 35: 19-28.
60. Duangkumpha K, Techasen A, Loilome W, Namwat N, Thanan R, et al. (2014) BMP-7 blocks the effects of TGF- ${ }^{2}$-induced EMT in cholangiocarcinoma. Tumour Biol 35: 9667-9676.

61. Park Y, Kim JW, Kim DS, Kim EB, Park SJ, et al. (2008) The Bone Morphogenesis Protein-2 (BMP-2) is associated with progression to metastatic disease in gastric cancer. Cancer Res Treat 40: 127-132.

62. Park Y, Kang MH, Seo HY, Park JM, Choi CW, et al. (2010) Bone morphogenetic protein-2 levels are elevated in the patients with gastric cancer and correlate with disease progression. Med Oncol 27: 1192-1199.

63. Choi YJ, Kim ST, Park KH, Oh SC, Seo JH, et al. (2012) The serum bone morphogenetic protein-2 level in non-small-cell lung cancer patients. Med Oncol 29: 582-588.

64. Fei ZH, Yao CY, Yang XL, Huang XE, Ma SL (2013) Serum BMP-2 upregulation as an indicator of poor survival in advanced non-small cell lung cancer patients. Asian Pac J Cancer Prev 14: 5293-5299.

65. Maes K, Nemeth E, Roodman GD, Huston A, Esteve F, et al. (2010) In anemia of multiple myeloma, hepcidin is induced by increased bone morphogenetic protein 2. Blood 116: 3635-3644.

66. Haka AS, Shafer-Peltier KE, Fitzmaurice M, Crowe J, Dasari RR, et al. (2002) Identifying microcalcifications in benign and malignant breast lesions by probing differences in their chemical composition using Raman spectroscopy. Cancer Res 62: 5375-5380.

67. Baker R, Rogers KD, Shepherd N, Stone N (2010) New relationships between breast microcalcifications and cancer. Br J Cancer 103: 1034-1039.

68. Hassan MQ, Maeda Y, Taipaleenmaki H, Zhang W, Jafferji M, et al. (2012) miR-218 directs a Wnt signaling circuit to promote differentiation of osteoblasts and osteomimicry of metastatic cancer cells. J Biol Chem 287: 42084-42092.

69. Liu F, Bloch N, Bhushan KR, De Grand AM, Tanaka E, et al. (2008) Humoral bone morphogenetic protein 2 is sufficient for inducing breast cancer microcalcification. Mol Imaging 7: 175-186. 